\title{
CLINICAL ISOLATES OF E.COLI IN PIGS - ANTIMICROBIAL RESISTANCE AND PERSPECTIVES TO OPTIMIZE ANTIBIOTIC ADMINISTRATION
}

\author{
Igor Stojanov ${ }^{1 *}$, Jasna Prodanov Radulović ${ }^{1}$, Andrea Lauková ${ }^{2}$, \\ Luba Grešáková ${ }^{2}$, Jelena Petrović ${ }^{1}$, Radomir Ratajac ${ }^{1}$, Ivan Pušić ${ }^{1}$ \\ ${ }^{1}$ Scientific Veterinary Institute "Novi Sad”, Novi Sad, Republic of Serbia; \\ ${ }^{2}$ Institute of Animal Physiology, Centre of Biosciences of \\ the Slovak Academy of Sciences, Košice, Slovakia
}

\section{Abstract}

Modern livestock production inevitably involves the use of antimicrobial drugs. Adequate use thereof depends on the application of appropriate biosecurity measures and timely and accurate diagnostics of diseases. Administration of antimicrobial drugs without previous identification of "zootechnical issues" or relevant laboratory analyses may lead to the development of antimicrobial resistance (AMR). Surveillance and monitoring of AMR is conducted according to prescribed procedures and includes sampling at slaughter line. Development of antimicrobial resistance (AMR) and occurrence of resistance gene may be a result of inadequate use of antibiotics and uncontrolled trading of antibiotics. In this research, we monitored the presence of specific bacterial species belonging to the Enterobacteriaceae family and their sensitivity to particular antibiotics in diverse animal categories on pig farms over the breeding period. The aim of the study was to establish the following: development of antimicrobial resistance by isolated bacteria, resistance to several diverse groups of antibiotics, and potential alternatives to antibiotics in the cases when therapy is required. The research confirmed the development of AMR during pig production process, which is often manifested as multiple resistance (group of penicillin and synthetic penicillin drugs, aminoglycosides, fluoroquinolones, tetracyclines).

Key words: pig farming, antibiotics, resistance, bacteriocins

${ }_{1}^{*}$ Corresponding author: igor@niv.ns.ac.rs 


\title{
KLINIČKI IZOLATI E. COLI KOD SVINJA - ANTIMIKROBNA REZISTENCIJA I MOGUĆNOST SMANJENJA UPOTREBE ANTIBIOTIKA
}

\author{
Igor Stojanov ${ }^{1^{*}}$, Jasna Prodanov Radulović ${ }^{1}$, Andrea Lauková2, \\ Luba Grešáková ${ }^{2}$ Jelena Petrović ${ }^{1}$, Ivan Pušić ${ }^{1}$ \\ ${ }^{1}$ Naučni institut za veterinarstvo „Novi Sad“, Novi Sad, Srbija \\ ${ }^{2}$ Institute of Animal Physiology, Centre of Biosciences of the \\ Slovak Academy of Sciences, Košice, Republika Slovačka
}

\section{Kratak sadržaj}

Savremena stočarska proizvodnja podrazumeva upotrebu antimikrobnih lekova. Njihovo adekvatno korišćenje zavisiće od postignutih biosigurnosnih mera i pravovremenog i tačnog uspostavljanja dijagnoze oboljenja koja se uoče. Ako se iz bilo kog razloga antibiotici administriraju bez prethodno utvrđenih zootehničkih propusta ili laboratorijskih analiza može doći do pojave i razvoja antimikrobne rezistencije (AMR). Kontrola AMR prati se na procedurama predviđen način (uzorkovanjem na liniji klanja), ali se često prenebregava da se tokom proizvodnog ciklusa, zbog neadekvatne upotrebe antibiotika može razviti rezistencija i dovesti do širenja gena rezistencije. U našem radu smo pratili prisustvo pojedinih bakterijskih vrsta iz familije Enterobacteriacae u različitim proizvodnim kategorijama, tokom odgoja, na farmama svinja i njihovu osetljivost prema pojedinim antibioticima. Cilj rada je da se utvrdi da li su izolovane bakterije razvile antimikrobnu rezistenciju, da li se javila rezistencija na više različitih grupa antibiotika kao i da se ponudi alternativa upotrebi antibiotika u okolnostima kad je neophodna terapija. Ispitivanje je pokazalo da se tokom odgoja i tova svinja razvija AMR i da se često javlja kao multipna rezistencija (grupa penicilinski i sintetskih penicilina, aminoglikozidi, florhinoloni, tetraciklini).

Ključne reči: odgoj svinja, antibiotici, rezistencija, bakterocini

\section{INTRODUCTION}

Competitive interactions between microbes in natural environment resulted in the development of antimicrobial compounds as a necessary "weapon" aimed at limiting the presence and growth of specific organisms that make the ecosystem microflora. The creation of such substances has enabled the pro- 
ducer-organisms to effectively inhibit the growth of the competitor-microflora and thus provide favorable conditions to disperse in the environment (Huttner et al., 2013). The presence of antimicrobial substances inevitably instigated the development of microbial defense mechanisms adopted by bacteria to overcome the cidal and static effects of antimicrobials and survive in natural environments (Hibbing et al., 2010; Kassen et al., 2004; Boles et al., 2004; Kirisits et al., 2005). From the perspective of the nature, the described mechanisms cannot be considered a problem for antimicrobial resistance. Since the discovery of antibiotics and their use for therapy and later for preventive purposes or for the boost of growth in livestock production, they have been putting tremendous pressure on all microorganisms in all of their habitats and contact sites. Thus, in order to survive in the environment, the microbes have developed diverse forms of resistance. It could be concluded that from the moment of producing antimicrobial substances in surplus, the response of the nature was to develop and spread antimicrobial resistance.

Application of antibiotics in livestock production involves therapeutic use for treating infections, the use for prophylactic purposes and growth promotion to improve production potential and decrease undesirable effects of bacteria (Jarlier et al., 2012) and stimulate productive and genetic potential of animals (Kittitat et al., 2018). Administration of antibiotics over a short or prolonged period might result in development of antimicrobial resistance, which reduces and/or completely eliminates the effectiveness of antibiotics. The consequences of antimicrobial resistance are associated not only with decreased production results but also with poor therapy prospects in diseased animals.

Antimicrobial resistance nullifies the effects of antibiotics in preventing adverse effects of existing bacterial flora or limits the presence of pathogenic organisms through static/cidal effects. Transfer of microbial resistance gene poses a particular problem. Both humans and animals can be exposed to highly resistant bacteria through different transmission routes, even if they are not close to the carriers. Resistant strains of enteric bacteria pose the most serious threat to human health (Huttner et al., 2013). This problem is of major significance, since pathogens that have acquired resistance are able to colonize animals and/or humans who had previously not been exposed to antibiotics, resulting in therapeutic failure.

The control of antimicrobial resistance in domestic animals is related to the examination of susceptibility of isolated microorganisms at slaughter line (Commission Implementing Decision, 2013). Such monitoring practices can bring about different results on antimicrobial resistance as compared to the findings obtained during grower and fattening phase. Namely, during grower and fattening stage, the animals are exposed to antibiotics, which results in development of antimicrobial resistance. In the period before slaughtering, the 
use of antibiotics is prohibited in order to eliminate antibiotic residues from meat and contribute to reduction or elimination of the resistance (Commission Implementing Decision, 2013).

In this research, we monitored the presence of particular bacterial species from the Enterobacteriaceae family in different production categories of pigs on farms and their susceptibility to specific antibiotics. The aim of the study was to determine the following: development of antimicrobial resistance in isolated bacteria, resistance to several different groups of antibiotics, and potential alternatives to antibiotics in the cases when therapy is necessary.

\section{MATERIAL AND METHODS}

The material for examination was obtained from eight pig farms. The samples included rectal swabs from piglets, parenchymatous organs and intestines of dead animals. All the animals selected for the sampling were subjected to antibiotic therapy due to different health problems (respiratory and digestive diseases). A total of 26 rectal swabs and 9 samples from dead pigs were examined. Antibiograms were prepared from 28 isolated bacterial strains. Before collecting rectal swabs from piglets, the swabs were immersed into sterile saline and transported to the laboratory in cooling boxes on the same day. The swabs and organs of dead animals were inoculated onto the MacConkey (Biokar), XLD (Biokar) and blood agar (TSA (Biokar) $+5 \%$ defibrinated sheep blood). Identification of isolated bacteria from the Enterobacteriaceae family was performed using biochemical tests (oxidase and catalase test, indole, methyl red, urea, citrate).

Suspension for determination of antimicrobial susceptibility of isolated bacteria was prepared according to CLSI procedure (CLSI, 2016). Microbial suspension was prepared from 24-hour old cultures matching McFarland 0.5 standard. Using a swab, the suspension was transferred to a Mueller-Hinton agar (Biokar, France), and antibiotic discs (Bioanalyse, Turkey) were placed onto the cultures. Inhibition zone readings were performed according to manufacturer's instructions.

Antibiotic disks and method were controlled according to manufacturer's instruction. Reference strain (Escherichia coli ATCC 25922) was used as control test. Suspension of E. coli ATCC 25922 was tested on three antibiotics (Tetracycline $30 \mu \mathrm{g}$, Gentamicin $10 \mu \mathrm{g}$ and Ceftriaxone $15 \mu \mathrm{g}$ ). 


\section{RESULTS}

During the investigation period, rectal swabs of piglets or organs of dead piglets at nursery/growing stage (from the pre-weaning period at 4-5 weeks of age to the pre-fattening stage at 10-12 weeks of age) were analyzed. Considering that this is the most critical period of piglet breeding cycle, the animals received diverse antibacterial therapies. Drug administration was indicated according to clinical findings of digestive disorders manifested by various forms of diarrhea with lethal outcomes. Besides digestive disorders, respiratory symptoms were recorded and relevant antibacterial therapy was introduced. Administration of antimicrobial drugs was not indicated by previous laboratory examination. The therapy was applied without a prior evaluation of microbiological status and antibiotic susceptibility of bacterial flora.

Table 1 illustrates the data on susceptibility/resistance of bacteria isolated from piglets. The data are expressed as a percentage, according to each individual farm.

Table 1. Resistance of bacteria isolated from piglets by farms, expressed as a percentage (\%)

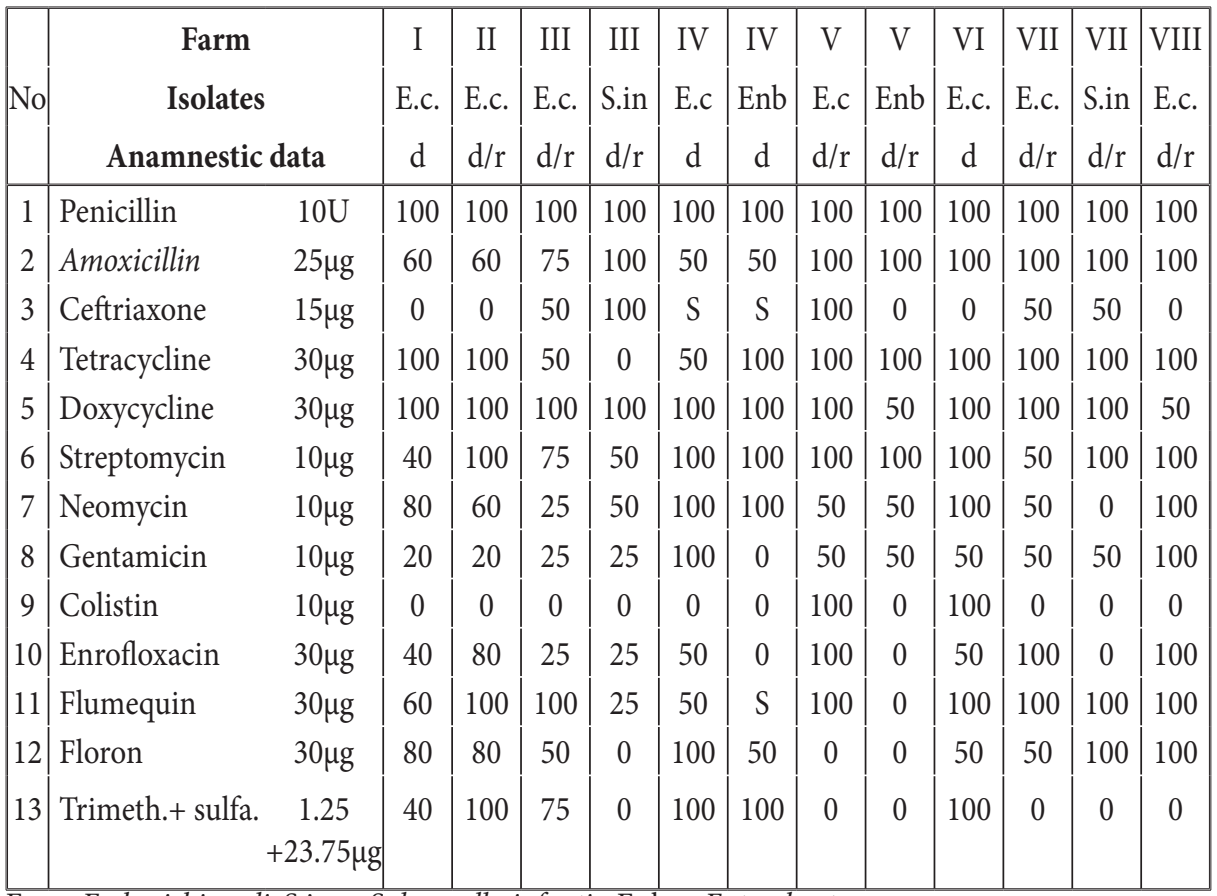

E.c. - Escherichia coli, S.in. - Salmonella infantis, Enb. - Enterobacter sp.

$\mathrm{d}$ - diarrhea, $\mathrm{r}$ - respiratory syndrome 


\section{DISCUSSION}

The control of antimicrobial resistance is carried out according to the Directive on the monitoring and reporting of antimicrobial resistance in zoonotic and commensal bacteria and pertains to determination of susceptibility and/or changes in the susceptibility of specific bacterial species that may be isolated from food-producing animals or from foods (Salmonella spp., Campylobacter jejuni, Campylobacter coli, Escherichia coli, Enterococcus faecium and Enterococcus faecalis). Sampling procedures and monitoring of bacterial species, which are potential carriers of the resistance, are laid down in relevant legislation and regulations on the collection of materials for examination from the slaughterhouses, the amount which will be proportional to the annual production output in the country (Commission Regulation, 2005). Our research was aimed at monitoring the occurrence of resistance in strains isolated from animals at the beginning of production cycle. The isolated strains of E. coli, Salmonella enetrica serovar infantis and Enterobacter spp. are part of bacterial flora commonly found in pigs. Confirmed presence of resistant bacterial strains strongly indicated previous application of substantial amounts of antibiotics. Similar research was reported by Kittitat et al. (2018) who investigated the occurrence of antimicrobial resistance in two pig groups - the first one was fed food containing antibiotics while the second one was fed without antibiotic supplementation. Potential risk of the presence of the aforementioned strains implicates different aspects of inadequate biosecurity measures on the farms. The transfer of resistant strains from the parts of the farm where the piglets are produced and reared, to the parts used for fattening, pose a direct danger of the potential entry of resistant strains in the human food chain. Molecular testing identified ESBL gene and confirmed the interrelation between the presence of resistant strains of $E$. coli in poultry meat from the shops and strains of $E$. coli isolated from human rectal swabs (Overdevest et al., 2011). Moreover, the transmission of resistant strains from animals to humans can occur through direct contact of farm staff ( $\mathrm{Da}$ Costa et al., 2013), or using farm equipment or accessories (Wenzel and Edmond, 2010), which poses a high risk and threat for human health.

During our research, a high percentage of resistance of isolated strains was monitored with regards to bacterial species and the farm. Our investigation of sensitivity of some bacteria from the Enterobacteriaceae family revealed high resistance rates in piglets at grower stage. The highest resistance was determined for penicillin, tetracycline and doxycycline, whereas resistance to amoxicillin, neomycin and streptomycin was somewhat lower. Multiple resist- 
ance was observed on all farms, except on farm I. On almost all farms, multiple resistance to three or more different antibiotic groups was recorded. The study from 2018 that included two farms - the first one used in-feed tiamulin and amoxicillin while the second one used feed without antibiotic supplements revealed the presence of multiple resistance of isolated enterobacterial strains on both farms. However, the prevalence was somewhat higher on the farm where the animals were fed antibiotics. In the same research, the authors established the highest resistance rate of enterobacteria in the post-weaning period and during growerstage (Kittitat et al., 2018). Our results correspond to the results of this research, especially for the resistance in piglets at grower stage. Investigation of antimicrobial resistance of $E$. coli strains isolated on pig farms revealed multiple resistance resulting from inadequate administration of antimicrobial drugs (Kallau et al., 2018). According to the available data (Lagha et al., 2017), tetracycline is most commonly used antibiotic in pig production and thus one of the causes of resistance of some strains (especially E.coli) to this antibiotic, which was also confirmed in our study. The development of resistance by isolated $E$. coli strains is of importance not only for pathogenic strains. Since this is a commensal organism and most important bacterium residing in digestive system, the resistance of these strains and potential transfer of resistance gene poses the highest risk for the entire natural environment (Skočková et al., 2015; Laube et al., 2014; Hinenoya et al., 2014).

Addressing the problem of antimicrobial resistance and prevention of its transfer within human population includes several approaches. Prevention of transmission of resistant bacterial strains among humans (horizontal - via immediate contact) through improved hygiene is one of the first steps. Limiting antibiotic administration by avoiding their imprudent use as therapeutics in cases when they are not appropriately indicated and stimulating the development of novel antibiotic drugs are of crucial importance (Carlet et al., 2011; Jarlier et al., 2012). The aforementioned measures for preventing transmission of resistance gene carrier strains are also applicable in pig industry. Considering the specificities of livestock production providing relevant zoohygienic and biosecurity measures as well as the costs of novel antibiotic drugs, the implementation of such measures is quite a challenging task. The use of feed supplements that affect the intestinal $\mathrm{pH}$ level (prebiotics) or the gut microbiota composition (probiotics) are potential alternatives to antibiotic administration.

Bacteriocins are peptides synthesized mostly by Gramm positive organisms. The effects thereof are bacteriostatic and/or bactericidal (Lagha et al., 2017). The majority of bacteriocins shows static and/or cidal effects limited to the bacteria closely related to producer - species. However, antibacterial effects of some bac- 
teriocins extends to a wider range of different bacterial species (Riley and Wertz, 2002). Some bacteriocins act in synergy with conventional antibiotics, thus enabling reduction of bacteriostatic concentrations (Cavera et al., 2015). The mechanisms of action of bacteriocins are diverse. They can target bacterial cell wall and stimulate cell lysis or affect protein synthesis inside the cell, i.e. bacterial gene expression (Cotter et al., 2013). Bacteriocins are divided into four classes including (I) lantibiotics, (II) non-lantibiotics or unmodified peptides, (III) high molecular mass peptides, and (IV) circular peptides (Heng and Tagg, 2006).

The options for bacteriocins application are determined by the specific purpose of their use, i.e. whether they are used in food industry or in livestock production. In general, purified bacteriocins can be used for both purposes and directly affect the microflora (food or digestive system) or as bacteriocin-producing strains which inhibit the growth of pathogenic bacteria. In pig production, bacteriocins (nisin or enterocin) are combined with an antibiotic to improve its effectiveness or can be used as specific bacteriocins-producing strains manifesting static effects on Streptococcus suis, E. coli, Haemophilus parasuis, Treponema spp., Bacteroides spp. (Lagha et al., 2017).

\section{CONCLUSION}

The development of resistance is apparent in piglets at grower stage, and our research indicated the necessity of monitoring bacterial susceptibility throughout all the stages of livestock production. Such finding strongly suggests that transmission of resistant strains to humans does not occur only through food (examination at slaughterhouses and in the market) but also through direct contact of farm staff.

To avoid the overuse of antibiotics and reduce and/or eliminate antimicrobial resistance, it is necessary to implement all biotechnical measures to prevent stress and immune decline as well as to prevent introduction of pathogenic strains in farms. Moreover, the application of bacteriocin-producing strains could complement or completely replace antibiotics. Administration of probiotics along with bacteriocin-producing strains can be considered potential sound alternative to antibiotics and contribute to reduction of antimicrobial resistance.

\section{ACKNOWLEDGEMENT}

This article is based on the work from scientific and technological cooperation between the Republic of Serbia and the Slovak Republic, bilateral project number: 337-00-107/2019-09/14 and SK-SRB-18-0001, project title: Bacteriocins, a safe way to inhibit antibiotic resistant bacteria from pigs for healthy farm- 
ing, supported by the Ministry of Education, Science and Technological Development of the Republic of Serbia, and by APVV agency of Slovak Republic.

\section{Authors' contributions}

IS, JPR and AL made contributions to conception and design of the article, they were involved in data collection and drafting the manuscript. IP, JP, JPR and IS contributed to data collection on farms, present diseases, microbiological results and estimate of antimicrobial resistance. LG revised the manuscript critically and together with IS, JP and JPR prepared the final draft of the manuscript. All authors have read and approved the final manuscript.

\section{Competing interests}

\section{The authors declare that they have no competing interests.}

\section{REFERENCES}

1. Boles B.R., Thoendel M., Singh P.K. 2004. Self-generated diversity produces "insurance effects" in biofilm communities. Proc. Natl. Acad. Sci. U. S. A. 101, 47, 16630-16635, doi: 10.1073/pnas.0407460101.

2. Carlet J., Collignon P., Goldmann D., Goossens H., Gyssens I.C., Harbarth S, Jarlier V., Levy B.S., N’Doye B., Pittet D., Richtmann R., Seto H.W., Van der Meer M.W.J. and Voss A. 2011. Society's failure to protect a precious resource: antibiotics. Lancet, 378, 9788, 369-371, doi: 10.1016/S01406736(11)60401-7.

3. Cavera V.L., Arthur T.D., Kashtanov D., Chikindas M.L. 2015. Bacteriocins and their position in the next wave of conventional antibiotics. Int J Antimicrob Agents 46, 5, 494-501, doi: 10.1016/j.ijantimicag.2015.07.011.

4. Clinical Laboratory Standards Institute (CLSI) 2016. Performance Standards for Antimicrobial Susceptibility Testing.

5. Cotter P.D., Ross R.P., Hill C. 2013. Bacteriocins - a viable alternative to antibiotics? Nat Rev Microbiol 11, 2, 95-105, doi: 10.1038/nrmicro2937.

6. Da Costa P.M., Loureiro L., Matos A.J.F. 2013. Transfer of multidrug-resistant bacteria between intermingled ecological niches: the interface between humans, animals and the environment. Int J Environ Res Public Health 10, 1,278-294, doi: 10.3390/ijerph10010278.

7. Heng N.C.K. and Tagg J.R. 2006. What's in a name? Class distinction for bacteriocins. Nat Rev Microbiol 4, 160, doi:10.1038/nrmicro1273-c1. 
8. Hibbing E.M., Fuqua C., Parsek R.M., Peterson S.B. 2010. Bacterial competition: surviving and thriving in the microbial jungle. Nat Rev Microbiol. 8, 1, 15-25, doi:10.1038/nrmicro2259.

9. Hinenoya A., Shima K., Asakura M., Nishimura K., Tsukamoto T., Ooka T., Hayashi T., Ramamurthy T., Faruque M.S. Yamasaki S. 2014. Molecular characterization of cytolethal distending toxin gene-positive Escherichia coli from healthy cattle and swine in Nara, Japan. BMC Microbiol; 14, 97, 1-13, doi: 10.1186/1471-2180-14-97.

10. Huttner A., Harbarth S., Carlet J., Cosgrove S., Goossens H., Holmes A., Jarlier V., Voss A., Pittet D. 2013. Antimicrobial resistance: a global view from the 2013 World Healthcare-Associated Infections Forum. Antimicrob. Resist Infect. Control. 2, 31, doi: 10.1186/2047-2994-2-31.

11. Jarlier V., Carlet J., McGowan J., Goossens H., Voss A., Harbarth S. 2012. Priority actions to fight antibiotic resistance: results of an international meeting. Antimicrob Resis Infect Contr, 1, 1, 17, doi: 10.1186/2047-29941-17.

12. Kallau N.H.G., Wibawan I.W.T., Lukman D.W., Sudarwanto M.B. 2018. Detection of multi-drug resistant (MDR) Escherichia coli and tet gene prevalence at a pig farm in Kupang, Indonesia. Journal of Advanced Veterinary and Animal Research, 5, 4, 388-396, doi: 10.5455/javar.2018.e289.

13. Kassen R., Llewellyn M., Rainey P.B. 2004. Ecological constraints on diversification in a model adaptive radiation. Nature, 431, 7011, 984-988, doi: 10.1038/nature02923.

14. Kirisits M.J., Prost L., Starkey M., Parsek M.R. 2005. Characterization of colony morphology variants isolated from Pseudomonas aeruginosa biofilms. Appl. Environ. Microbiol, 71, 8, 4809-4821, doi: 10.1128/ AEM.71.8.4809-4821.2005.

15. Lugsomya K., Yindee J., Niyomtham W., Tribuddharat C., Tummaruk P., Hampson D.J., Prapasarakul N. 2018. Antimicrobial Resistance in Commensal Escherichia coli Isolated from Pigs and Pork Derived from Farms Either Routinely Using or Not Using In-Feed Antimicrobials. Microb Drug Resist. 24(7):1054-1066. doi: 10.1089/mdr.2018.0154

16. Ben Lagha, A., Haas, B., Gottschalk, M., Greiner D. 2017. Antimicrobial potential of bacteriocins in poultry and swine production. Veterinary Research 48, 22, doi:10.1186/s13567-017-0425-6.

17. Laube H., Friese A., von Salviati C., Guerra B., Rosler U. 2014. Transmission of ESBL/AmpC-producing Escherichia coli from broiler chicken farms to surrounding areas. J Vet Mic, 172, 3-4, 519-27, doi: 10.1016/j. vetmic.2014.06.008. 
18. Official Journal of the European Union. 2013. Decisions, Commission Implementing Decision on the monitoring and reporting of antimicrobial resistance in zoonotic and commensal bacteria (notified under document C(2013) 7145) (Text with EEA relevance) (2013/652/EU)

19. Official Journal of the European Union. 2005.Commission Regulation (EC) No 2073/2005 on microbiological criteria for foodstuffs (Text with EEA relevance) (OJ L 338, 22.12.2005, p. 1-31)

20. Overdevest I., Willemsen I., Rijnsburger M., Eustace A., Xu L., Hawkey P., Heck M., Savelkoul P., Vandenbroucke-Grauls C., Kim van der Zwaluw, Huijsdens X., Kluytmans J. 2011. Extended-spectrum beta-lactamase genes of Escherichia coli in chicken meat and humans, The Netherlands. Emerg Infect Dis. 17, 7, 1216-1222, doi: 10.3201/eid1707.110209.

21. Riley M.A. and Wertz J.E. 2002. Bacteriocins: evolution, ecology, and application. Ann. Rev. Microbiol 56, 117-137, doi: 10.1146/annurev. micro.56.012302.161024.

22. Skočková A., Koláčková I., Bogdanovičová K., Karpíšková R. 2015. Characteristic and antimicrobial resistance in Escherichia coli from retail meats purchased in the Czech Republic. J Food Cont, 47, 401-6, doi:10.1016/j. foodcont.2014.07.034.

23. Wenzel R.P.W. and Edmond M.B. 2010. Infection control: the case for horizontal rather than vertical interventional programs. Int J Infect Dis, 14, Suppl 4), S3-S5, doi: 10.1016/j.ijid.2010.05.002.

Received: 13.06.2020.

Accepted: 12.12.2020. 